\title{
Impact of Plant Growth Regulators on Fruit Production
}

\author{
Karishma Sebastian $^{1 *}$, M.S. Arya, U.R. Reshma ${ }^{1}$, S.J. Anaswara ${ }^{1}$ and Syama S. Thampi ${ }^{2}$ \\ ${ }^{1}$ Department of Pomology and Floriculture, ${ }^{2}$ Department of Post Harvest Technology, \\ College of Agriculture, Vellayani, Kerala Agricultural University, Thiruvananthapuram, India \\ *Corresponding author
}

\section{A B S T R A C T}

\begin{tabular}{|c|c|}
\hline Keywords & \multirow{8}{*}{$\begin{array}{l}\text { Plant hormones are signal molecules produced within the plant, and occur in extremely } \\
\text { low concentrations. Phytohormones determine the formation of flowers, stems, leaves, } \\
\text { shedding of leaves, and development and ripening of fruits. They shape the plant, affecting } \\
\text { seed growth, time of flowering, sex of flowers, senescence of leaves and fruits. Hormones } \\
\text { are vital for plant growth and lacking them, plants would be mostly a mass of } \\
\text { undifferentiated cells. Plant growth regulators include auxins, gibberellins, cytokinins, } \\
\text { ethylene, growth retardants and growth inhibitors. The production of poor quality fruits is } \\
\text { a matter of common experience. It would be therefore worthwhile to improve the yield and } \\
\text { quality of fruit crops by foliar application of plant growth regulators. The use of growth } \\
\text { regulators has become an important component of agro-technical procedures for most of } \\
\text { the cultivated plants and especially for fruit plants. In this review, we focus on the role of } \\
\text { plant growth regulators on fruit production. }\end{array}$} \\
\hline & \\
\hline & \\
\hline & \\
\hline Artic & \\
\hline & \\
\hline & \\
\hline & \\
\hline
\end{tabular}

\section{Introduction}

Phytohormones are organic substances produced naturally in higher plants, controlling growth or other physiological functions at a site remote from its place of production and active in minute amounts. But, plant growth regulators includes naturally occurring phytohormones, their chemical analogs, hormone releasing agents, hormone sensitivity altering agents and hormone synthesis inhibitors (Hajam et al., 2017). Also plant growth regulators are defined as organic substances (other than nutrients), which in small amount promote, inhibit or otherwise modify any physiological process in plants.
Thus the use of plant growth regulators has resulted in outstanding achievements in several fruit crops with respect to growth, yield and quality. Fruit trees are considered high value crops and even small modifications in production efficiency, product quality or enhanced appeal have the potential to significantly increase product value.

In this review, impact of naturally occurring phytohormones, hormone synthesis inhibitors, hormone releasing agents and hormone sensitivity altering agents on fruit production are briefed. 


\section{Impact of naturally occurring phytohormones on fruit production}

Auxin, gibberellins, cytokinin, abscissic acid, ethylene, brassinosteroids, salicylic acid, polyamines, methyl jasmonates and triacontanol are the naturally occurring plant hormones.

\section{Auxin}

Auxins are a group of phytohormones produced in the shoot and root apices and they migrate from the apex to the zone of elongation. Auxins promote the growth along the longitudinal axis of the plant and hence the name (auxeing: to grow or to increase). The term, auxin was introduced by Kogl. Auxins are widely distributed throughout the plant however, abundant in the growing tips such as coleoptile tip, buds, root tips and leaves. Indole Acetic Acid (IAA) is the only naturally occurring auxin in plants. At lower concentration, auxin stimulate growth while at higher concentration they retard growth. They are characterized by causing cell enlargement and stem elongation in plants. They are also active in development of branches in plants and are associated with apical dominance.

Optimum concentration and combination of IBA and NAA on rooting potential of guava stooled shoots was studied by Lal et al., (2007). The treatment IBA (7500 ppm) gave maximum rooting percentage $(96.67 \%)$, average number of roots per shoots (46.93), average root length $(8.45 \mathrm{~cm})$ and survival (75\%) after transplanting in the field. The optimum concentration of IBA must have caused the mobilization and utilization of carbohydrates and nitrogen fraction with the presence of cofactors at wounding portion, which help better root initiation, number of roots per shoots and average root length. The highest survival of rooted stooled shoots may be due to well developed root system, which might cause better absorption of water and mineral nutrients from the soil and ultimately retaining higher percentage of survival in the field.

Fruit growth after fertilization is dependent on auxin produced in developing seeds. Influence of auxin produced by the achenes of strawberry on the growth of the receptacle of strawberry was studied by Galston (1994). The strawberry fruit is actually a swollen receptacle whose growth is regulated by auxin produced by the seeds, which are actually achenes- the true fruits. When the achenes are removed, the receptacle fails to develop normally and spraying the achene-less receptacle with IAA restores normal growth and development in strawberry, which implies the importance of auxin in fruit development.

Application of 2,4-D spray (20 ppm) at or shortly after bloom effectively thins the number of Esbal clementine mandarin fruits without affecting total yield, reducing the percentage of unmarketable fruit to 13 per cent and increasing the mean size of marketable fruit (Duarte et al., 2006). Thinning effect is not related to an auxin induced ethylene synthesis, but results from the selective enhancement of the growth of some fruits by the 2,4-D application.

Effect of plant growth regulators on yield of pomegranate (Punica granatum L.) cv. Ganesh was studied by Reddy and Prasad (2012). Nine treatments with three growth regulators, viz., NAA at 20, 30 and $40 \mathrm{ppm}$; 2,4-D at 20, 30 and $40 \mathrm{ppm}, \mathrm{GA}_{3}$ at 25, 50 and $75 \mathrm{ppm}$ and control (water spray) were sprayed three times starting at full bloom and, subsequently, at 45 and 90 days after fruit set. Results revealed that application of 2,4-D at $40 \mathrm{ppm}$ gave significantly high aril percent, maximum number of fruits (64.00) which resulted in highest fruit yield of $16.78 \mathrm{~kg}$ plant $^{-1}$, as against $7.41 \mathrm{~kg}$ in the control. 
Rajendran (1983) reported that 2,4-D at 20 ppm as two foliar sprays at three and four months after planting promoted vegetative growth, induced early shooting of plants by about 12 days, advanced crop duration by 22 days, improved fruit quality in terms of TSS and total sugars and increased yield by 88 per cent in Banana var. Palayankodan.

NAA applied at $5,000 \mathrm{mg} \mathrm{L}^{-1}$ to java apple (Syzygium samarangense) produced the broadest fruits $(6.60 \times 7.82 \mathrm{~cm})$ and yielded $16.79 \mathrm{t} \mathrm{ha}^{\mathbf{- 1}}$; whereas the control treatment produced smaller fruits $(5.40 \times 8.06 \mathrm{~cm})$ and a lower fruit yield of $14.81 \mathrm{t} \mathrm{ha}^{-1}$ (Muchjajib et al., 2016). Auxin plays a vital role in cell division as well as elongation of cells leading to increase in size of fruit.

Effect of NAA on fruit set and fruit retention percentage of mango cv. Keitt was studied by Osama et al., (2015). Result showed that 50 ppm NAA treatment surpassed $\mathrm{GA}_{3}$ and citric acid in enhancing fruit set and fruit retention percentage, yield and fruit quality traits. An external application of NAA might have increased the level of auxin in plant, which reduced the drop resulting in higher retention of fruit at various stages. Higher level of auxin in plant and fruit found helpful in mobilization of nutrient or food material and increases the retention of fruits.

\section{Gibberellic acid}

Though gibberellins were originally discovered as the cause of a disease of rice that stimulated internode elongation, endogenous gibberellins influence a wide variety of developmental processes. In addition to stem elongation, gibberellins control various aspects of seed germination, including the loss of dormancy and the mobilization of endosperm reserves.

Mango (Mangifera indica L.) stones presoaked with gibberellic acid $\left(\mathrm{GA}_{3}\right)$ at 100 ppm recorded maximum (85.67\%) germination followed by $\mathrm{KNO}_{3} 1$ per cent $(81.66 \%)$. While minimum germination percentage $(63.33 \%)$ was observed in control (no treatment) (Kolekar et al., 2017). The promotive effect of $\mathrm{GA}_{3}$ on seed germination is due to role of $\mathrm{GA}_{3}$ in activating alpha amylase enzyme which converts starch into simple carbohydrate and liberate chemical energy which is used in the activation of embryo.

$\mathrm{GA}_{3}$ application $80 \mathrm{ppm}$ to one year old strawberry plants promotes vegetative growth and runner production (Kumar et al., 2012). This may be due to inhibition of flowering and corresponding increase in epidermal and parenchymatous cell growth.

Black spot symptoms, caused by Alternaria alternata, developed in persimmon fruits during prolonged storage at $-1{ }^{\circ} \mathrm{C}$, can be significantly reduced by $\mathrm{GA}_{3}$ treatment. A preharvest treatment with gibberellic acid $\left(\mathrm{GA}_{3}\right)$ extended the storage life of the fruit by delaying both black spot development and fruit softening (Eshel et al., 2000). Conversely, treatment of persimmon fruits with paclobutrazol (PBZ), an inhibitor of gibberellin synthesis, enhanced black-spot development and fruit softening during storage, which indicates the role of $\mathrm{GA}_{3}$ in disease tolerance. Also, black spot symptoms caused by $A$. alternata, in persimmon, are related to the ability of the fungus to produce endo-1,4- $\beta$-glucanase in developing lesions. In this study, it was found that production of endo-1,4- $\beta$-glucanase from PBZ treated fruits as the carbon source, was enhanced by 150 per cent over production in the presence of cell walls from control fruits, whereas endo1,4-b-glucanase production in the presence of cell walls from $\mathrm{GA}_{3}$ treated fruits was reduced by 49 per cent relative to controls.

GA applied at the concentration of $2,500 \mathrm{mg}$ $\mathrm{L}^{-1}$ produced the longest fruits $(6.12 \times 9.14$ 
$\mathrm{cm}$ ) and yielded $18.23 \mathrm{t} \mathrm{ha}^{-1}$ in java apple (Syzygium samarangense), whereas control treatment produced smaller fruits $(5.40 \times 8.06$ $\mathrm{cm})$ and a lower fruit yield of $14.81 \mathrm{t} \mathrm{ha}^{-1}$ (Muchjajib et al., 2016).

$\mathrm{GA}_{3}$ treatment had a significant effect on the phenylalanine ammonia lyase (PAL) activity. After $30 \mathrm{~min}$ of incubation, the PAL activity expression of the cinnamic acid yield was the highest (36.91 nmol min ${ }^{-1} \mathrm{mg}$ protein ${ }^{-1}$ ) in wax apple, whereas the control fruits produced the lowest amount of cinnamic acid (21.37 nmol $\min ^{-1} \mathrm{mg}$ protein $\left.{ }^{-1}\right)$. A high degree of positive correlation was observed between the PAL activity and anthocyanin formation in the treated ripening fruits (Khandaker et al., 2013).

DPPH (2,2-diphenyl-1-picrylhydrazyl) radical scavenging activity measured in the wax apple fruit extracts was affected by the $\mathrm{GA}_{3}$ (Khandaker et al., 2013). Also a high correlation $\left(\mathrm{R}_{2}=0.86\right)$ was observed between the total phenolic content and DPPH measurements in the $50 \mathrm{mg} \mathrm{GA}_{3} \mathrm{~L}^{-1}$ treated fruits.

Influence of plant growth regulators (NAA, 2, 4-D, and gibberellic acid) on sex ratio and fruit set in Dashehri mango was studied by Ahmed et al., (2012). Foliar application of 15 ppm NAA produced 14 per cent more perfect flowers (45.12\%) than control plants $(31.22 \%)$ and maximum fruit set $(84.84 \%)$ was recorded in $\mathrm{GA}_{3}(15 \mathrm{ppm})$ application followed by NAA (35 ppm). Application of $\mathrm{GA}_{3}$ induced the production of enzymes attributed to improved fruit set (Sponsel, 1995) by playing a role in the post fertilization event.

Effect of plant growth regulators on percent fruit drop per panicle at different stages of fruit growth in Dashehri mango was studied by Ahmed et al., (2012). Fruit drop took place at three successive stages of fruit growth, i.e., pea, marble, and at pre-harvest stage. Plants sprayed with $\mathrm{GA}_{3}$ at $35 \mathrm{ppm}$ were recorded with the lowest fruit drop (66.84\%) having 31.31 per cent more fruit retention than control plants. Reduction in the fruit drop as a response of $\mathrm{GA}_{3}$ is due to an increase in initial growth of ovaries, ultimately reduced magnitude of the peak of abscission.

Least percentage of fruit drop (30\%) was observed in $20 \mathrm{mg} \mathrm{GA}_{3} \mathrm{~L}^{-1}$ treated branches of wax apple whereas the control branches showed the highest fruit drop (46\%) (Khandaker et al., 2013). Also $\mathrm{GA}_{3}$ treated fruits of wax apple showed significant effect on $\mathrm{K}^{+}$content (Khandaker et al., 2013), which regulates the translocation of photosynthates, protein synthesis, ionic balance and plant stomatal opening and also known as a quality nutrient because of its important effects on fruit quality factors such as size, shape, colour, taste, shelf life and fibre quality.

Gibberellic acid increases bunch and berry weight of 'Emperatriz' seedless grapes and the response depends on the phenological stage of vine at treatment date and on the concentration applied (Casanova et al., 2009). From berry fruit set to 21 days later, $80 \mathrm{mg} \mathrm{L}^{-1}$ $\mathrm{GA}_{3}$ increased commercial berry weight by 50-90 per cent, depending on the year, reaching similar size to that of Aledo seeded grape, used as comparison. This effect is due to an increase on the total sugars content, which, in turn, increases total water content. Indeed, because of the absence of seeds, seedless grape has a lack of suitable sink capacity and the concentration of sucrose that reaches the berry is lower than that of seeded ones, but $\mathrm{GA}_{3}$ treated seedless berry increase sink activity (Zhenming et al., 2008), measured as sugar uptake, and thus increase berry weight.

Thompson Seedless berries treated with $\mathrm{GA}_{3}$ in combination with girdling developed 
heavier berries $(280.9 \mathrm{~g})$ compared to control $(239.7 \mathrm{~g})$, whereas $\mathrm{GA}_{3}$ treatment alone gave berries with 274.3g (Abu-Zahra, 2010). Girdling of grapevines resulted in an increase in carbohydrate concentration above girdle and the use of $\mathrm{GA}_{3}$ enhanced the enlargement of grape fruits.

Influence of gibberellic acid on fruit cracking index of sweet cherry cvs. Van and Sunburst was studied by Usenik et al., (2005). Treatment with $\mathrm{GA}_{3} 20 \mathrm{ppm}$, at transition from green to straw yellow colour of fruits resulted in lower cracking index in Van and Sunburst. After four hour standing in water, there was low fruit cracking (except untreated fruits of cv. Sunburst), and fruit cracking was increased after six hour in both cultivars and of both treated and untreated fruits. Gibberellic acid treated fruits had rather more water uptake and lower cracking index, which shows the higher epidermis elasticity of treated fruits. By increasing cell elasticity, $\mathrm{GA}_{3}$ could reduce the fruit cracking when the fruit wetting was less than 4 hour.

\section{Cytokinin}

The word for cytokinins is a generic name for all naturally occurring substances that are known to promote cell division. The term cytokinin was proposed by Letham in 1963. They are also known to delay senescence. The first naturally occurring cytokinin was found in corn and is referred as zeatin.

The most widely distributed cytokinins are the synthetic benzyladenine and kinetin. Kinetin was discovered from the tobacco pith callus and the chemical substance was identified as 6-furfuryl aminopurine. The natural cytokinin appears to be made principally in apical root meristem, inflorescences and developing fruits.

Induction of parthenocarpic fruit set in apple cvs. Golden Delicious and Jonagold using N-
(2-chloro-4-pyridinyl)-N'-phenyl urea (CPPU) and GA were investigated by Bangerth and Schroder (1994). When applied in combination, CPPU and gibberellins had a positive synergistic effect on parthenocarpic fruit set and this is due to the fact that CPPU diminishes the rapid metabolism of the applied GA, allowing them to act for a longer duration. The parthenocarpic fruits induced by CPPU and GA had an increased length to diameter ratio also.

CPPU 10 ppm at mustard + pea stage recorded maximum yield $\left(107.00 \mathrm{~kg}\right.$ tree $\left.{ }^{-1}\right)$ in mango cv. Kesar (Kulkarni et al., 2017). The promoting effect of CPPU on fruit set and fruit retention is achieved by reducing abscissic acid content.

CPPU has great potential to increase the size of kiwifruit when applied to fruitlets 21 days after flowering, either as a $5 \mathrm{mg}$ litre $^{-1}$ dip or as a $5 \mathrm{mg}$ litre $^{-1}$ spray (Patterson et al., 1993). Dipping increased mean fresh weight of fruit at harvest by 43 per cent and spraying by 33 per cent. Most of the increase in fruit size was because of an increase in the volume of "small" isodiametric parenchyma cells in the outer pericarp. The volume of "large" ovoid parenchyma cells in the outer pericarp was not affected by CPPU treatment.

Benzyl adenine at $7.5 \mathrm{mg} \mathrm{L}^{-1}$ affected the rate of somaclonal variation indirectly by increasing multiplication rate and inducing adventitious shoot proliferation in Cavendish banana (Musa AAA cv. 'Zelig') (Bairu et al., 2006).

\section{Abscisic acid}

The name abscisic acid (ABA) was given because it was found in high concentrations in newly abscissed or freshly fallen leaves. Abscisic acid is also known as stress hormone, because in plants under water stress 
ABA plays a role in closing the stomata. It causes bud dormancy. Also it accumulates within seeds during fruit maturation, preventing seed germination within the fruit, or germination before winter. Abscisic acid effects are degraded within plant tissues during cold temperatures or by its removal by water washing in out of the tissues, releasing the seeds and buds from dormancy.

Anthocyanin accumulation in Pinot noir grape berry skins grown under high night temperatures was lower than that in berries grown under low night temperatures. ABA treatment enhanced anthocyanin accumulation under high night temperatures to almost the same level as under low night temperatures (Mori et al., 2005). Mechanism for the increase of anthocyanin accumulation in grape skin by ABA treatment seems to involve the induction of VvmybA1, a putative regulatory gene of anthocyanin biosynthesis.

\section{Ethylene}

Ethylene is a simple gas that is produced in small quantities by many plant tissues and they serve as a very powerful regulator of growth and development. They are found very prominently in physiologically matured fruits undergoing ripening.

Effect of post harvest spray of different concentrations (100, 200, 400, 600 and 800 ppm) of ethrel (2-chloroethyl phosphonic acid) on ripening and colour development in Dashehari mango fruits was investigated by Gurjar et al., (2017). Ethrel spray at 600 ppm induced uniform ripening with attractive yellow colour within four days while untreated control fruits failed to ripen uniformly and remain light green even after eight days of storage. This indicates that degradation of chlorophyll pigments in fruit peel in ethrel treated fruits was more rapid than in untreated fruits, which is due to accelerated rate of diffusion of exogenous ethylene into peel of ethrel treated fruits. Also total carotenoid content in ethrel treated fruits increased from 0.807 to 7.12 and $7.14 \mathrm{mg}$ $100 \mathrm{~g}^{-1}$ in 600 and $800 \mathrm{ppm}$ of ethrel treated fruits, respectively after four days of treatment, whereas in untreated fruits pulp developed $7.05 \mathrm{mg} 100 \mathrm{~g}^{-1}$ even after eight days of storage. Higher carotenoid content in ethrel treated fruits could be due to enhancement in activity of carotenoid $\beta$ hydroxylase enzyme responsible for carotene synthesis and improper development of total carotenoid pigments in pulp of control samples could be due to delayed ethylene biogenesis.

Exogenous application of ethrel (2Chloroethyl phosphonic acid) at 240 to 960 ppm induced female and intersexual flowers along with male flowers on genetically male plants of papaya (Carica papaya L. var. honey dew) grown in field conditions (Kumar, 1997). Phenotypic expression of sex reversal was found associated with qualitative and quantitave changes in free soluble proteins and peroxidase isozymes.

Hazarika et al., (2016) reported that application of $400 \mathrm{ppm}$ ethrel to tissue cultured papaya (Carica papaya) cv. Red Lady resulted in the highest TSS (16.91\%), total and reducing sugars (10.17 and $7.58 \%)$, ascorbic acid (73.97\%), and sugar: acid ratio (79.49) and lowest titrable acidity $(0.128 \%)$. Increase in TSS may be the result of a higher accumulation of metabolites and a quick conversion of starch into soluble sugars during the fruit development in response to growth regulators (Agrawal and Dikshit, 2010). The reduction in titratable acidity with ethrel may be due to its action on the fast conversion of organic acids and starch into reducing and non-reducing sugars and their derivatives through higher respiration and carbon assimilation activity during rapid 
ripening process (Yadav et al., 2001). The increase in sugar content in ethrel treated plants may be due to the rapid ripening of fruits and accelerated activities of hydrolytic enzymes, which is associated with high metabolic changes in fruits, leading to the conversion of complex polysaccharides and organic acids into simple sugars through higher respiration and carbon assimilation activity (Yadav et al., 2001).

\section{Brassinosteroids}

Brassinosteroid is a steroidal hormone, produced by terpinoid pathway. It was first identified from rape seed (Brassica napus) pollen grains, and hence the name brassinosteroids. It promotes pollen germination and pollen tube growth.

Role of brassinosteroid in fruit ripening was studied by Chai et al., (2013). They analysed Brassinosteroid (BR) content and BR receptor gene FaBRI1 expression during 'Akihime' strawberry fruit development and reported that BR levels increased during the later developmental stages, and the mRNA expression levels of FaBRI1 increased rapidly from white to initial red stages, suggesting that $\mathrm{BR}$ is associated with fruit ripening. This was further confirmed by exogenous application of BR and its inhibitor brassinazole (BZ) to big-green fruit, which significantly promoted and inhibited strawberry fruit ripening, respectively. In addition, both BR content and FaBRI1 expression reached their peak levels in smallgreen fruit, suggesting that BR might also be involved in early strawberry fruit development.

Exogenous application of Epibrassinolide treatments (45 and $60 \mathrm{ng} \mathrm{g}^{-1} \quad \mathrm{FW}$ ) on Kensington Pride mango, significantly advanced the onset of the climacteric peak of ethylene production and respiration rate by 2 and 1 day(s), respectively (Zaharah et al., 2012). Both of these treatments also had a higher climacteric ethylene production peak (4.81 and $5.74 \mathrm{nmol} \mathrm{C}_{2} \mathrm{H}_{4} \mathrm{~kg}^{-1} \mathrm{~h}^{-1}$ ) and respiration rate $\left(4.87\right.$ and $5.06 \mathrm{mmol} \mathrm{CO}_{2}$ $\mathrm{kg}^{-1} \mathrm{~h}^{-1}$ ) compared with the control. Furthermore, all Epibrassinolide treatments significantly improved mango skin color development between the second day and seventh day of fruit ripening.

Foliar brassinolide spray significantly affected the enzyme activities and calcium content of litchi pericarp and reduced the fruit cracking (Peng et al., 2004). Spray of brassinolide solution on litchi leaves before blossom increased the content of watersoluble pectin, protopectin and calcium in the fruit pericarp, and reduced fruit cracking rate, suggesting an important role in increasing the commercial value of litchi fruits.

Post shooting bunch spray of brassinosteroid $2.0 \mathrm{mg} \mathrm{L} \mathrm{L}^{-1}$ yielded $114.46 \mathrm{t} \mathrm{ha}^{-1}$ in banana cv. Grand naine as against $84.24 \mathrm{t} \mathrm{ha}^{-1}$ in control (Rajan, 2017). This might be due to effect of brassinosteroids on cell elongation by increasing the cell permeability to water and osmotic solutes of the cells.

\section{Salicylic acid}

Mango cv. Amrapali sprayed with salicylic acid (SA) 100 ppm combined with urea 2 per cent recorded minimum fruit drop $(88.16 \%)$, maximum fruit retention (5.41) per panicle and highest yield per tree $(16.21 \mathrm{~kg})$ compared to control $(94.39 \%, 1.42$ and $6.6 \mathrm{~kg}$ tree $^{-1}$ respectively) (Mandal et al., 2015). The developing fruits need auxin in higher quantity and fruit drop occurs when auxin levels goes down. SA plays on important role in regulating number of physiological process including synthesis of auxin and/or cytokinin. Furthermore, nitrogen in the form of urea also triggered the synthesis of tryptophan, a 
precursor of auxin synthesis that inhibits fruit drop thus increasing fruit retention.

Salicylic acid effectively inhibits ethylene production in pear cell suspension cultures by blocking the conversion of 1aminocyclopropane-1-carboxylic acid to ethylene (Leslie and Romani, 1986).

The minimum physiological loss in weight (PLW) $(11.06 \%)$ was observed in Amrapali mango fruits treated with salicylic acid (200 ppm), while the maximum PLW (16.55\%) was recorded in the untreated control mango fruits at the end of storage period, i.e. $9^{\text {th }}$ day after storage (Reddy et al., 2016). Higher PLW in untreated (control) mango fruits might be due to their active metabolism in terms of respiration and transpiration, which might have led to greater loss of water during storage resulting in visually perceptible shriveling of 'Amrapali' mango fruits. The lower PLW in the salicylic acid treated mango fruits can be directly correlated with reduced respiration, transpiration and suppressed ethylene production. This suggests that salicylic acid might have reduced respiration and transpiration, which concomitantly delayed senescence of the treated mango fruits.

Effects of salicylic acid concentration on reducing fruit fungal decay in selva strawberry was studied by Babalar et al., (2007). Fungal decay decreased rapidly in berries treated with salicylic acid in a concentration dependent manner from 1 to 2 mmol and did not differ from 2 to $4 \mathrm{mmol}$. Salicylic acid causes a rapid increase in $\mathrm{H}_{2} \mathrm{O}_{2}$ production in plants and $\mathrm{H}_{2} \mathrm{O}_{2}$, as a signal molecule, activates the plant's systemic resistance against pathogens.

Trees of citrus cv. Valencia Late oranges were sprayed with salicylic acid at different concentrations $(2,3,4,6,8,9 \mathrm{mM})$ ten days before anticipated harvest and fruits were harvested and stored at $5^{\circ} \mathrm{C}$ for 93 days to investigate the effects of salicylic acid on fruit rot and chilling injury. Fruits were analyzed before storage and after 31, 62 and 93 days of storage and found that salicylic acid at $9 \mathrm{mM}$ reduced fruit rot from 11.09 per cent to 4.56 per cent and chilling injury from 6.35 per cent to 2.85 per cent (Ahmad et al., 2013). Fruits treated with salicylic acid were firmer as measured by different textural properties such as rind puncture, tensile and fruit firmness which make them less susceptible to fungus and disease pathogens.

\section{Polyamines}

Amount of free polyamines in cuttings of Pinot noir, a low abscising cultivar and Merlot a high abscising cultivar of grapes (Vitis vinifera L.) was studied by Aziz, (2003). In inflorescences of Pinot noir, the free polyamines amounts decreased gradually after anthesis and remained important even after full bloom. However, in inflorescences of Merlot the content of total free polyamines decreased before anthesis and reached a lower level thereafter. Thus, the high level of free polyamines observed in inflorescences of the low abscising cultivar suggests that these compounds may have an important function in reproductive organ development and/or fertility. Also they pointed that polyamines act as signal molecules regulating the abscission processes, thus the application of exogenous spermidine, prior to flowering can markedly inhibits abscission.

Effect of various concentrations of polyamines, putrescine $(10 \mathrm{mM})$, spermidine $(0.1,1$ and $5 \mathrm{mM})$ and spermine $(2 \mathrm{mM})$ on peach (Prunus persica L. Batsch cv. Redhaven) fruit ripening was evaluated under field conditions by Bregoli et al., (2002). Treatments were performed 19 days before harvest. All polyamines strongly reduced or 
even nullified ethylene emission in the final days of fruit growth (109 and $111 \mathrm{dAFB})$. At harvest (111 dAFB), ethylene from polyamine-treated fruits was from almost 3(spermine) to 30 -fold (5 $\mathrm{mM}$ spermidine) lower than controls and not detectable with 1 $\mathrm{mM}$ spermidine. Polyamines inhibited the conversion of S-adenosyl methionine (SAM) to 1-Aminocyclopropane-1-carboxylic acid (ACC), the immediate precursor of ethylene, which gives this effect.

Efficiency of different concentrations of polyamines on physiological parameters of mango cv. Alphonso, seven days after spraying was studied by Mallikarjuna (2015). Highest transpiration rate $\left(0.336 \mathrm{~mol} \mathrm{H}_{2} \mathrm{O} \mathrm{m}{ }^{-2}\right.$ $\mathrm{Sec}^{-1}$ ) was recorded in putrescine at $250 \mathrm{ppm}$ and highest stomatal conductance and photosynthetic rate was observed with putrescine at $100 \mathrm{ppm}$.

\section{Methyl jasmonate}

Dong et al., (2016) demonstrated that methyl jasmonate treatment at concentrations of 50 and $100 \mu \mathrm{mol} \mathrm{L}^{-1}$ for half-red maturity fruit and $100 \mu \mathrm{mol} \mathrm{L^{-1 }}$ for green maturity fruit enhanced the antioxidant systems in Chinese winter jujube. The enhanced antioxidant systems inhibited decrease in firmness, suppressed fruit respiration rate, reduced $\mathrm{O}_{2}{ }^{-}$ production and the accumulation of $\mathrm{H}_{2} \mathrm{O}_{2}$.

\section{Triacontanol}

Triacontanol (TRIA) is a natural plant growth regulator found in epicuticular waxes. It is a straight chain 30 carbon alcohol $\left(\mathrm{CH}_{3}\left(\mathrm{CH}_{2}\right)_{28}\right.$ $\mathrm{CH}_{2} \mathrm{OH}$ ) and endogenous hormone which is active at very low concentration on the cell membranes and acts in combination with other long chain alcohols to regulate the formation of TRIM, a secondary messenger(s) of TRIA. Tricontanol is used to enhance the growth, chlorophyll content, photosynthesis, transpiration, stomatal conductance and uptake of nutrient in different fruit crops. It increases the amino acids, sugars and carbohydrates in plants. It also influences other metabolic processes in different fruit crops.

Effect of the bioregulators Agrispon and Ergostim on yield of apple (Malus pumila L.) variety Golden Delicious was studied by Dubravec et al., (1995). Agrispon is a nontoxic plant and mineral extract containing zeatin, triacontanol, and other components. Ergostim is an L-cysteine and folic acid derivative. Both products were applied twice, three weeks after flowering, and 10 to 15 days later the chlorophyll content of leaves increased throughout the season. Higher concentrations of leaf pigments favoured the biosynthesis of photosynthate, and had a positive effect on fruit yield also. Agrispon produced a 49 per cent yield increase above the control.

Kasambhai (2015) revealed that foliar application of triacontanol at $750 \mathrm{mg} \mathrm{L}^{-1}$ recorded maximum fruit set at pea and marble stage per panicle, minimum fruit drop at marble and harvest stage, maximum fruit retention at harvest stage and maximum number of fruits per tree. This might be due to the reason that application of tricontanol attributed to more efficient utilization of food for reproductive growth, flowering and fruit set, higher photosynthetic efficiency and enhanced source to sink relationship of the plant, increased uptake of nutrients and water, reduced transpiration and respiration, enhanced translocation and accumulation of sugar and other metabolites.

Thakur (2014) reported that fruit set, fruit retention and yield of apricot cv. New Castle was highest for triacontanol $7.5 \mathrm{ppm}(57.63$, 34.46 and 61.33 respectively) compared to control (47.94, 28.60 and 47.33). The increase 
in fruit set is probably due to the higher levels of carbohydrates and $\mathrm{C} / \mathrm{N}$ ratio because of improved photosynthesis.

\section{Impact of hormone synthesis inhibitors on fruit production}

\section{GA synthesis inhibitors}

\section{Paclobutrazol}

In Asian pear cv. Crisp, paclobutrazol treatment promoted lateral shoot growth, resulting in slender, horizontally spread shoots in contrast to the upright growth on controls (Huang et al., 1989).

Paclobutrazol applied to the collar region of sweet cherry (Prunus avium) trees cv. Rivan produced a significant reduction in shoot length and stimulation of flowering and this effect was proportional to dose of retardant (Grochowska and Hodun, 1997).

Six year old mango trees (Mangifera indica L.) of cv. Nam Dok Mai Twai No. 4 planted in high density system $(2.5 \mathrm{~m} \times 2.5 \mathrm{~m})$, after treating with paclobutrazol at the rate of $1.5 \mathrm{~g}$ $\mathrm{m}^{-2}$ to soil by spraying the basin significantly reduced the canopy size (19.90 per cent in height and 15.81 per cent in spread) in one year (Charnvichit and Tongumpai, 1991), which may be due to reduced gibberellin synthesis in the tissues (Sterett, 1985). This gave optimal canopy size for high density planting while the canopy of the control trees became overlapping. The effect of paclobutrazol on growth lasted for only one year after which normal growth resumed.

Paclobutrazol (5 g/ tree) induced early and profuse flowering, increases fruit set, reduced fruit drop and higher yield in mango cv. Alphonso and Prior (Randeep, 2012). Paclobutrazol application leads to the accumulation of carbohydrates (Wieland and
Wample, 1985) and low gibberellin content in tissues which creates a favourable condition for flowering.

Paclobutrazol $(80 \mathrm{ml} /$ tree $)$ produced earlier flowers (125.79 days) with respect to panicle emergence in mango cv. Alphonso compared to control (165.04 days) (Gaurang et al., 2016). Paclobutrazol induced flower bud formation by lowering gibberellin content in the shoot tips.

Foliar spray and soil drench application of cultar at zero, 10, 20, 40 and $60 \mathrm{~g}^{\text {tree }}{ }^{-1}$ to mango (Mangifera indica L.) cv. Dashehari prior to flower bud differentiation have significant effect on floral malformation (Singh and Dhillon, 1992) and lowest incidence of floral malformation was achieved with soil application of cultar $(20 \mathrm{~g}$ tree $\left.^{-1}\right)$.

Japanese pear (Pyrus pyrifolia Nakai cv. Hosui) fruits sprayed with paclobutrazol at 30 days after full bloom significantly suppressed the occurrence of water core, whereas gibberellin spray leads to severe case of water core (Sakuma et al., 1995).

Trees of Gardiner Delicious apple treated with paclobutrazol at petal fall + four weeks produced fruit with higher flesh calcium and less bitter pit, cork spot, and senescent breakdown following regular air storage and thus increased the storage life of fruits (Greene, 1991).

Potentiality of paclobutrazol (PBZ) to mitigate the stress caused due to presence of salt in the soil in mango (Mangifera indica L.) field was studied by Srivastav et al., (2010). Results indicated that PBZ $(1500 \mathrm{mg} / \mathrm{l})$ mitigated the salinity stress and reduced ion leakage of mango seedlings by 64 per cent over non PBZ treated salinized plants. Salt treated plants without PBZ showed 4.65 folds 
more ion leakage than non salt treated plants without PBZ. The application of PBZ significantly reduced the ion leakage in salt treated plants. Also paclobutrazol minimizes the negative effects of salinity with evidence of less membrane damage by upregulating the endogenous production of proline and antioxidant enzymes like superoxide dismutase, catalase and peroxidase.

\section{Prohexadione-Ca}

Prohexadione calcium, an inhibitor of gibberellin biosynthesis, not only retard shoot growth but it can also alter plant metabolism to impart resistance to insects and diseases.

Vigorous shoot growth can negatively influence fruit quality, tree productivity and efficiency of plant protection in orchard. Therefore, there is a need for controlling the shoot growth in fruit trees, which can be achieved by using inhibitors of gibberellin biosynthesis, which will retard tree growth and, consequently, improve the productivity. Basak (2007) studied the effect of prohexadione-Ca on shoot growth of young apple trees of $\mathrm{cv}$. Jonagold and found that prohexadione-Ca at $75 \mathrm{mg} \mathrm{dm}^{-1}$ applied twice reduced the tree size and the structure of canopy was improved.

Impact of hormone releasing agents on fruit production

\section{Ethephon}

Dass et al., (1975) carried out an investigation to increase the efficacy of ethephon by combining it with urea and calcium carbonate for induction of flowering in pineapple. Ethephon at a concentration as low as $25 \mathrm{ppm}$ in combination with urea $(2 \%)$ and calcium carbonate $(0.04 \%)$ was able to induce more than 90 per cent flowering after 50 days of treatment. Addition of either urea or calcium carbonate increased the effectiveness of ethephon for induction of flowering. Ethephon treatments were found to be markedly superior to control.

Application of ethephon $0.2 \mathrm{ml} \mathrm{L}^{-1}$ advanced the harvesting of banana $\mathrm{cv}$. Grand naine bunches by 80 days as against 106 days in control (Rajan, 2017). The activity of ethephon has been attributed primarily to its ability to release ethylene in plant tissues. Ethylene stimulates respiration and protein synthesis in certain immature fruits, which may trigger a chain of biochemical events required for ripening.

\section{Impact of hormone sensitivity altering agents on fruit production}

\section{1-Methylcyclopropene}

1-Methylcyclopropene (1-MCP) is an ethylene antagonist widely used to retain quality and prolong the postharvest storage period of various climacteric fruits in which ethylene plays a critical role in regulation of the ripening process.

The green rachis in clusters of table grapes provides an important indication of the freshness of the produce after storage. Postharvest exposure to 1-MCP at $1 \mathrm{~mL} \mathrm{~L}^{-1}$ delayed rachis browning in table grape variety 'Thompson seedless', because of reduced respiration and ethylene production in 1-MCP treated rachis (Li et al., 2015).

Exposure to $1-\mathrm{MCP}$ at $1 \mathrm{~mL} \mathrm{~L}{ }^{-1}$ remarkably reduced development of superficial scald incidence on 'Wonderful' pomegranate fruits after 12 weeks of cold storage at $7^{\circ} \mathrm{C}$, which is due to reduced malondialdehyde levels and polyphenol oxidase (PPO) enzyme activity as a result of 1-MCP, which are processes associated with peel senescence and browning (Defilippi et al., 2006). 
Li et al., (2016) found that exposure of dragon fruit $\mathrm{cv}$. 'Bilu' to $1-\mathrm{MCP}$ at $1 \mathrm{~mL} \mathrm{~L}^{-1}$ delayed scale senescence as observed after 16 days of cold storage at $10^{\circ} \mathrm{C}$ followed by five days under shelf life conditions at $20^{\circ} \mathrm{C}$.

Exposure to $1-\mathrm{MCP}$ at $1 \mathrm{~mL} \mathrm{~L}^{-1}$ preserved postharvest quality of prickly pear fruits, as indicated by inhibition of peel colour change and reduction of decay development (Li et al., 2016).

The exogenous application of bioregulators act as a powerful tool not only for enhancing growth, productivity and quality of fruits but also in combating the ill effects generated by various biotic and abiotic stresses in plants in the near future. There by it aids to enhance potential crop yield and alleviate hunger and malnutrition in the ever increasing human population of the world.

\section{References}

Abu-Zahra, T. R. 2010. Berry size of Thompson seedless as influenced by the application of gibberellic acid and cane girdling. Pakistan Journal of Botany, 42(3): 1755-1760.

Agrawal, S. and Dikshit, S. N. 2010. Studies on the effect of plant growth regulators on qualitative characters of sapota cv. Cricket Ball. Indian Journal of Horticulture, 67: 177-80.

Ahmad, S., Singh, Z., Khan, A. S., and Iqbal, Z. 2013. Pre-harvest application of salicylic acid maintain the rind textural properties and reduce fruit rot and chilling injury of sweet orange during cold storage. Pakistan Journal of Agricultural Science, 50(4): 559-569.

Ahmed, W., Tahir, F. M., Rajwana, I. A., Raza, S. A., and Asad, H. U. 2012. Comparative evaluation of plant growth regulators for preventing premature fruit drop and improving fruit quality parameters in 'Dusehri'mango. International Journal of Fruit Science, 12(4): 372-389.

Aziz, A. 2003. Spermidine and related metabolic inhibitors modulate sugar and amino acid levels in Vitis vinifera L.: possible relationships with initial fruitlet abscission. Journal of Experimental Botany, 54(381): 355-363.

Babalar, M., Asghari, M., Talaei, A., and Khosroshahi, A. 2007. Effect of pre-and postharvest salicylic acid treatment on ethylene production, fungal decay and overall quality of Selva strawberry fruit. Food chemistry, 105(2): 449-453.

Bairu, M. W., Fennell, C. W., and Staden, J. V. 2006. The effect of plant growth regulators on somaclonal variation in Cavendish banana (Musa AAA cv. 'Zelig'). Scientia Horticulturae, 108(4): 347-351.

Bangerth, F., and Schroder, M. 1994. Strong synergistic effects of gibberellins with the synthetic cytokinin N-(2-chloro-4-pyridyl)$\mathrm{N}$-phenylurea on parthenocarpic fruit set and some other fruit characteristics of apple. Plant Growth Regulation, 15(3): 293-302.

Basak, A. 2007. The effect of prohexadione-Ca on shoot growth and cropping of young apple trees of Jonagold cv. Roczniki Akademii Rolniczej w Poznaniu. 41: 261-268.

Bregoli, A. M., Scaramagli, S., Costa, G., Sabatini, E., Ziosi, V., Biondi, S., and Torrigiani, P. 2002. Peach (Prunus persica) fruit ripening: amino ethoxy vinyl glycine (AVG) and exogenous polyamines affect ethylene emission and flesh firmness. Physiologia Plantarum, 114(3): 472-481.

Casanova, L., Casanova, R., Moret, A., and Agustí, M. 2009. The application of gibberellic acid increases berry size of Emperatriz seedless grape. Spanish Journal of Agricultural Research, 7(4): 919-927.

Chai, Y. M., Zhang, Q., Tian, L., Li, C. L., Xing, Y., Qin, L., and Shen, Y. Y. 2013. Brassinosteroid is involved in strawberry fruit ripening. Plant Growth Regulation, 69(1): 63-69.

Charnvichit, S. and Tongumpai, P. 1991. Effect of paclobutrazol on canopy size control and flowering of mango cv. Nam Dok Mai Twai no. 4, after hard pruning. Acta Horticulture, 291: 60-66.

Dass, H. C., Randhawa, G. S., and Negi, S. P. 1975. Flowering in pineapple as influenced by ethephon and its combinations with urea 
and calcium carbonate. Scientia Horticulturae, 3: 231-238.

Defilippi, B. G., Whitaker, B. D., Hess-Pierce, B. M., and Kader, A. A. 2006. Development and control of scald on Wonderful pomegranates during long term storage. Postharvest Biology and Technology, 41: 234-243.

Dong, Y., Zhi, H. H., Xu, J., Zhang, L. H., Liu, M. P. and Zong, W. 2016. Effect of methyl jasmonate on reactive oxygen species, antioxidant systems, and microstructure of Chinese winter jujube at two major ripening stages during shelf life. The Journal of Horticultural Science and Biotechnology, 91(3): 316-323.

Duarte, A., Trindade, D. T. G., and Guardiola, J. L. 2006. Thinning of 'Esbal'clementine with 2, 4-dichlorophenoxyacetic acid. Influence on yield, fruit size and fruit quality. In: Proceedings of the International Society of Citriculture Vol. 2, pp. 929-933.

Dubravec, K., Dubravec, I., and Manitasevic, J. 1995. The effect of the bioregulators agrispon and ergostim on the vegetative and reproductive growth of apples. Journal of Sustainable Agriculture, 5(2): 73-83.

Eshel, D., Ben-Arie, R., Dinoor, A., and Prusky, D. 2000. Resistance of gibberellins treated persimmon fruit to Alternaria alternata arises from the reduced ability of the fungus to produce endo-1, 4- $\beta$ glucanase. Phytopathology, 90(11): 12561262.

Galston, A. 1994. Life Processes of Plants. Scientific American Library, New York, 493p.

Gaurang, P. D., Patel, B. N., Desai, K. D., Patel, N. K. and Patel, B. B. 2016. Influence of paclobutrazol for earliness in mango cv. Alphonso. International Journal of Science, Environment and Technology, 5(5): $2713-2718$.

Greene, D. W. 1991. Reduced rates and multiple sprays of paclobutrazol control growth and improve fruit quality of delicious apples. Journal of American Society of Horticultural Science, 116(5): 807-812.

Grochowska, M. J. and Hodun, M. 1997. The dwarfing effect of a single application of growth inhibitors to the root stem connection - the collar tissue - of five species of fruit trees. Journal of Horticultural Science, 72(1): 83-91.

Gurjar, P. S., Verma, A. K., Dikshit, A., and Shukla, D. K. 2017. Effect of ethrel spray on the ripening behaviour of mango (Mangifera indica L.) variety Dashehari. Journal of Applied and Natural Science, 9(3): 1619-1623.

Hajam, M. A., Hassan, G. I., Bhat, T. A., Bhat, I. A., Rather, A. M., Parray, E. A., Wani, M. A., and Khan, I. F. 2017. Understanding plant growth regulators, their interplay: For nursery establishment in fruits. International Journal of Chemical Studies, 5(5): 905-910.

Hazarika, T. K., Sangma, B. D., Mandal, D., Nautiyal, B. P., and Shukla, A. C. 2016. Effect of plant growth regulators on growth, yield and quality of tissue cultured papaya (Carica papaya) cv. Red Lady. Indian Journal of Agricultural Science, 86(3): 404-408.

Huang, H., Cao, S. Y., Qiao, X. S., and Lu, R. 1989. The effect of paclobutrazol on growth of some Asian pears. Scientia Horticulturae, 38: 43-47.

Kasambhai, M. S. 2015. Effect of foliar application of chemicals on fruit retention, yield and quality of mango (Mangifera indica L.) cv. Kesar. M.Sc. (Hort) thesis. Navsari Agricultural University, Navsari, $128 \mathrm{p}$.

Khandaker, M. M., Boyce, A. N., Osman, N., Golam, F., Rahman, M. M., and SofianAzirun, M. 2013. Fruit development, pigmentation and biochemical properties of wax apple as affected by localized Application of $\mathrm{GA}_{3}$ under field conditions. Brazilian Archives of Biology and Technology, 56(1): 11-20.

Kolekar, S. N., Kadam, A. S., and Gend, D. G. 2017. Effect of different organics and chemicals treatments on germination, growth and success of softwood grafting in mango during nursery stage. International Journal of Chemical Studies, 5(6): 880884.

Kulkarni, S. S., Patil, S. S., and Magar, S. D. 2017. Effect of plant growth regulators on 
yield and quality of mango (Mangifera indica L.) cv. Kesha. Journal of Pharmacognosy and Phytochemistry, 6(5): 2309-2313.

Kumar, A. 1997. Feminization of androcious papaya leading to fruit set by ethrel and chlorflurenol. Acta Horticulturae, 463: 251-259.

Kumar, R., Bakshi, M., and Singh, D. B. 2012. Influence of plant growth regulators on growth, yield and quality of strawberrry (Fragaria $x$ Ananassa Duch.) under U.P. sub tropics, Asian Journal of Horticulture, 7(2): 434-436.

Lal, S., Tiwari, J. P., Awasthi, P., and Singh, G. 2007. Effect of IBA and NAA on rooting potential of stooled shoots of guava (Psidium guajava L.) cv. Sardar. Acta Horticulturae, 735: 193-196.

Leslie, C. A. and Romani, R. J. 1986. Salicylic acid: a new inhibitor of ethylene biosynthesis. Plant Cell Reports, 5(2): 144146.

Li, L., Kaplunov, T., Zutahy, Y., Daus, A., Porat, R., and Lichter, A., 2015. The effects of 1methylcyclopropene and ethylene on postharvest rachis browning in table grapes. Postharvest Biology and Technology, 107: 16-22.

Li, L., Lichter, A., Chalupowicz, D., Gamrasni, D., Goldberg, T., Nerya, O., Ben-Arie, R. and Porat, R. 2016. Effects of the ethylene action inhibitor 1-methylcyclopropene on postharvest quality of non climacteric fruit crops. Postharvest Biology and Technology, 111: 322-329.

Mallikarjuna, K. 2015. Effect of polyamines and triacontanol on morpho-physiological behaviour of mango cv. Alphonso under rainy season of konkan agro-climatic conditions. M.Sc. (Hort) thesis. Dr. Balasaheb Sawant Konkan Krishi Vidyapeeth, Dapoli, 107p.

Mandal, B. K., Rani, R., and Ray, R. N. 2015. Effect of foliar spray of urea and growth regulators on marketable yield and quality of mango cv. Amrapali. International Journal of Agricultural Science, 7(7): 554558.

Mori, K., Saito, H., Goto-Yamamoto, N., Kitayama, M., Kobayashi, S., Sugaya, S.,
Gemma, H., and Hashizume, K. 2005. Effects of abscisic acid treatment and night temperatures on anthocyanin composition in Pinot noir grapes. Vitis, 44(4): 161-165.

Muchjajib, S., Muchjajib, U., and Jumee, M. 2016. Effects of GA and NAA application and fruit wrapping on yield and quality of java apple (Syzygium samarangense (Blum) Merrill \& Perry). In: Tustin, D. S. (ed.). Proceedings of International Symposia on the Physiology of Perennial Fruit Crops and Production Systems and Mechanisation, Precision Horticulture and Robotics. Acta Horticulturae, 1130. pp. 225-230.

Osama, H. M., Amro, S. M., and Saber, M. M. 2015. Effect of growth regulator, antioxidant and application date on fruiting and fruit quality of mango trees cv. Keitt. Journal of Agriculture Veterenery Science, 8: 87-95.

Patterson, K. J., Mason, K. A. and Gould, K. S. 1993. Effects of CPPU (N-(2-chloro-4-pyridyl)-N'-phenylurea) on fruit growth, maturity, and storage quality of kiwifruit. New Zealand Journal of Crop and Horticultural Science, 21(3): 253-261.

Peng, J., Tang, X., and Feng, H. 2004. Effects of brassinolide on the physiological properties of litchi pericarp (Litchi chinensis cv. nuomoci). Scientia Horticulturae, 101: 407-416.

Rajan, R. 2017. Effect of post-shooting bunch spray of chemicals on bunch characters and yield of banana (Musa paradisiaca L.) cv. Grand Naine. M.Sc. (Hort) thesis, Aspee College of Horticulture and Forestry, Navsari, 138p.

Rajendran, P. 1983. Effect of growth regulators and certain formulations on bunch development in banana var. Palayankodan. M.Sc. (Hort) thesis, Kerala Agricultural University, Thrissur, 106p.

Randeep, K. R. 2012. Chemical regulation of cropping in mango. M.Sc. (Hort) thesis, Kerala Agricultural University, Thrissur, $172 p$.

Reddy, P. and Prasad, D. M. 2012. Effect of plant growth regulators on fruit characters and yield of pomegranate (Punica granatum L.) cv. Ganesh. International Journal of Plant 
Animal and Environmental Science. 2(2): 91-93.

Reddy, S. V. R., Sharma, R. R., Srivastava, M., and Kaur, C. 2016. Effect of preharvest application of salicylic acid on the postharvest behavior of 'Amrapali' mango fruits during storage. Indian Journal of Horticulture, 73(3): 405-409.

Sakuma, F., Umeya, T., Tahira, K., Katagiri, S., and Hiyama. H. 1995. Effects of high temperature and/or gibberellin treatments during early fruit development on the occurrence of watercore in Japanese pear (Pyrus pyrifolia Nakai cv. Hosui). Journal of Japan Society of Horticultural Science, 64: 243-249.

Singh, Z. and Dhillon, B. S. 1992. Effect of paclobutrazol on floral malformation, yield and quality of mango (Mangifera indica L.). Acta Horticulture. 296: 51-54.

Sponsel, V.M. 1995. Gibberellin biosynthesis and metabolism, In: Davies, P. J. (ed.). Plant Hormones, Physiology, Biochemistry and Molecular Biology. Kluwer Academic Publishers, Dordrecht, Netherlands. p. 6697.

Srivastav, M., Kishor, A., Dahuja, A., and Sharma, R. R. 2010. Effect of paclobutrazol and salinity on ion leakage, proline content and activities of antioxidant enzymes in mango (Mangifera indica L.). Scientia Horticulturae, 125(4): 785-788.

Sterett, J. P. 1985. Paclobutrazol: a promising growth inhibitor for injection into woody plants. Journal of American Society for
Horticultural Science, 100: 4-8.

Thakur, K. 2014. Effect of bioregulators and plant growth promoting rhizobacteria on growth, yield and quality of apricot (Prunus armeniaca L.) cv. New Castle. M.Sc. (Hort) thesis. Dr. Yashwant Singh Parmar University of Horticulture and Forestry, Solan, 88p.

Usenik, V., Kastelec, D., and Stampar, F. 2005. Physicochemical changes of sweet cherry fruits related to application of gibberellic acid. Food Chemistry, 90: 663-671.

Wieland, W. F. and Wample, R. L. 1985. Effect of paclobutrazol on growth, photosynthesis and carbohydrate content of delicious apple. Scientia Horticulturae, 26:139-147.

Yadav, S. J., Bhatia, S. K., Godara, R. K., and Rana, G. S. 2001. Effect of growth regulators on the yield and quality of winter season guava cv. L-49. Haryana Journal of Horticultural Science, 30: 1-2.

Zaharah, S. S., Singh, Z., Symons, G. M., and Reid, J. B. 2012. Role of brassinosteroids, ethylene, abscisic acid, and indole-3-acetic acid in mango fruit ripening. Journal of Plant Growth Regulators, 31(3): 363-372.

Zhenming, N., Xuefeng, X., Yi, W., Tianzhong, L., Jin, K., and Zhenhai, H. 2008. Effects of leaf-applied potassium, gibberellin and source-sink ratio on potassium absorption and distribution in grape fruits. Scientia Horticulturae, 115: 164-167.

\section{How to cite this article:}

Karishma Sebastian, M.S. Arya, U.R. Reshma, S.J. Anaswara and Syama S. Thampi. 2019. Impact of Plant Growth Regulators on Fruit Production. Int.J.Curr.Microbiol.App.Sci. 8(02): 800-814. doi: https://doi.org/10.20546/ijcmas.2019.802.092 